\title{
ON NATIONAL CHARACTER AND PATRIOTISM. AN ANALYSIS OF THE VIEWS OF JULIAN OCHOROWICZ
}

\begin{abstract}
Time, history and culture are the main factors which influence a man's identity. The article presents the views of the Polish philosopher Julian Ochorowicz concerning the development of the Polish national character. It also discusses the problem of patriotism and stereotypes, which often distort the perception of a nation and its history. One of the interesting notions suggested by Ochorowicz is the so-called "collective national soul". He also analyses the problem of the Poles' "selfness", which he believes to be an obstacle preventing the development of an efficient state organisation.
\end{abstract}

Keywords: identity, national character, patriotism, collective national soul

1. Time and history as the foundations of national identity and patriotism. 2. Stereotypes and national identity. 3. Julian Ochorowicz on patriotism and the Polish national character.

4. Summary.

\section{TIME AND HISTORY AS THE FOUNDATIONS OF NATIONAL IDENTITY AND PATRIOTISM}

Understood as a series of transient facts, history may appear as a random collection of odd events taking place at different times, were it not for the consolidating role of thinking based on the community or state creation myth. Can the fleeting events of history be held back? Can time be stopped and tamed?

"The creators of religion and science have tried to accomplish this by introducing into our awareness the mythologised notions of reason, God, love, and death. (...) How, then, can time be captured in its changeability and prevented from flowing through 
us so fast? This insatiability becomes a long-time problem, both for the ordinary man and for the sage, the artist, the religious and the rationalist. The notion of time, if we want to understand it not only in metaphysical, but also in sociological and cultural terms, calls for a more precise definition with reference to the notion of myth. The methodological role of myth is comparable to the role of theory. Both myth and theory represent a concise way of thinking about the world; besides, both are created in order to explain and predict phenomena. (...) It was myth that provided the grounds for the theory of the role of the past in understanding the present." 1

It is important in this context to note the significance of metaphysics, which opens before man the possibility to "(...) freeze physical time by superimposing the mythical form of time upon it". 2 This way of viewing time and history should help us eliminate, at least in part, the contingency, precariousness and fortuity of the world, and understand ourselves and our place in the world. Myth as a stabilizer of time, so to speak, thus shows man his uniqueness as a particular and noteworthy subject who participates in the history of his family, community, state. This is why the history of every person's life is so important for them, eternal and divine. ${ }^{3}$ The category of time brings the future closer to us, and by referring to it, man becomes a subject by finding his own foundations, his family roots, that which precedes him and which warrants his functioning in a society. Myth also proves to be a kind of cultural sub-consciousness, a type of social metaphysics which defines the most primary rules of the social theatre. Thus, man can not only be referred to as a zoon politikona political animal, but also as a zoon methaphysikon - a metaphysical animal, living in a world of symbolic images providing the grounds

1 A. Drabarek, Mit jako czas skondensowany, Przegląd Filozoficzny - Nowa Seria 14(2005)3, 39-40.

2 L. Kołakowski, Obecność mitu, Wrocław 1994, 66.

3 Cf. H. Hesse, Myśli, Lublin 1996, 49. 
for social existence. In this context, a very significant role is played by the content and quality of these images, as well as their postulated and falsifiable correspondence to reality.

Such notions as filiation, lineage, parentage, genealogy, and descent, are categories on whose basis social order is established. ${ }^{4}$ Every society needs a clearly articulated "founding image", or a known history of its origins, as it is on this foundation that the subjectivity of individual members of the society is developed.

In this context, a very important role is played by the notion of patriotism, realized through tradition, authorities, and values, in a way constituting the social grammar. These are a condition for both the emergence and the historical continuance of a group. One could deliberate on whether patriotism is a kind of atavism, consisting in a primal, instinctive love for one's family and land, or whether it is the so-called hazy patriotism of which we are not fully aware, but which to some extent exists in every one of us. Anthropologists, sociologists and socio-biologists believe that it is natural for man to prefer his own group over foreign groups, and to accept first of all his own group's customs and culture. The fact that one is born of particular parents, in a particular place and time naturally situates us in ethnic groups and nations. Therefore, the concept of a national culture, understood also as national awareness, does not apply only to a particular, isolated domain in the life of a nation, but is expressed through events and processes, institutions and organisations. One of the many ways in which national culture can be understood is characterized by Maurycy Mochnacki ${ }^{5}$ as the history of awareness, or the way a nation has understood itself in

4 Cf. A. Drabarek, Kategoria ojca w poglądach Pierre Legendre, Psychologia Wychowawcza 48(2014)6, 112.

5 A political publicist, literary critic, and musician. A theoretician of Polish Romanticism, participant in and chronicler of the November Uprising. He was one of the major contributors to the Memoir of Polish Emigration, a periodical issued in Paris in the Polish language. One of the articles he authored was a treatise titled On the Spirit and Sources 
its existence. For, while remaining always the same, a nation was not the same at every stage of its history. A continued dialogue thus exists between the generations of the living and those who are already gone, and this is what helps us understand our identity. ${ }^{6}$ We may thus say that the fact that one belongs to a particular nation appears to be a process in which one inherits its cultural metaphysics. It is through upbringing and education, after all, that we absorb and internalize certain ideas, beliefs, and values which may be considered characteristic of a particular nation. Identity is built of the most prevalent features of a nation which we believe to be characteristic of a particular culture. By emphasizing certain features over others, we follow mostly the genealogical, geographical and economic criterion. Naturally, we cannot leave out political factors, just us we cannot ignore religion, language, literature, systems of education, or the system of values.

\section{STEREOTYPES AND NATIONAL IDENTITY}

Analysing the concept of national identity coexisting with a national culture, but also creating with it the specific "metaphysical architecture" of a nation, we should exercise utmost care lest we fall into the trap of common stereotypes, prejudices and simplifications. We must be prudent and guard against exaggeration and partiality, which may lead to unhealthy megalomaniac and ethnocentric tendencies, as well as to xenophobia. This type of biased reflections on the Polish national character may be found, for example, in a study entitled Der polnische Volkscharakter. Urteile und Selbstzeugnisse aus

of Poetry in Poland, in which he revealed himself as an advocate of the romantic attitude, giving primacy to intuition over the rational thought of Enlightenment.

6 A. Drabarek, Wartości w demokracji, Warszawa 2012, 160.

7 Cf. H. Sebald, Studying National Character Trough Comparative Content Analysis, Social Forces 40(1962)4, 318-322. 
vier Jabrbunderten by K. Ch. von Loesch. ${ }^{8}$ It presents various negative opinions on the culture and national character of Poles, and concludes with a thesis substantiating the inevitability of Poland's failure as an independent state. A much earlier, but equally negative opinion on Poles and their national character had been published on 6 March 1863 in the English Times, soon after the outbreak of the January Uprising in Poland. ${ }^{9}$ We were described as contentious, wilful, driven by whims rather than law, while at the same time displaying in our actions both nobility and laxity, symptomatic of a mixture of the Eastern and Western characters. This contraposition of the characteristic features of the East and the West, which highlighted their differences in religion, custom, and language was aimed first of all at presenting the Orient as a distinctly different culture. The perception of Eastern Europe as wild, unpredictable and related to the Orient first appeared in the 1820s in France. ${ }^{10}$

"The expansion of Russia to the territories of the Ottoman Empire linked the 'old' with the 'new' East. To the imagination of Western-European travellers and the authors of lexicons and encyclopaedias published in increasing numbers since the $18^{\text {th }}$ century, Eastern Europe became an intermediate formation - not as alien as the Orient, yet distant from civilization. Its characteristic features were backwardness, youthfulness in terms of civilisation, intellectual and material deficiency."11

Not only the features of an "oriental barbarity" were projected on Eastern Europe, however. Since the $18^{\text {th }}$ century, this region began

8 K. Ch. von Loesch, Der polnische Volkscharakter. Urteile und Selbstzeugnisse aus vier Jahrhunderten, Junker und Diinnhaupt, Berlin 1940.

9 Cf. M. Górny, Próby profesjonalizacji refleksji nad charakterem narodowym w XIX wieku, in: Klio Polska, Studia i materiały z dziejów historiografii polskiej XIX i XX wieku, Vol.6, Warszawa 2012, 11.

10 E. Adamowsky, Euro-Orientalism, Liberal Ideology and the Image of Russia in France, Bern 2006, 115.

11 M. Górny, op.cit., 14. 
to be perceived in terms of differences between the sexes. Such opinions may be found, for example, in the reflections of Gustav Klemm presented in his study Die Frauen. Kulturgeschichtliche Schilderungen des Zustandes Einflussesder Frauen in der verschiedenen Zonen und Zeitaltern, ${ }^{12}$ where he divided people into so-called female and male "races". In view of their intellectual potential and physical characteristics, he described the former in terms of passivity, emulation and physical weakness, and the latter in terms of activity, creativity and strength. In the article cited above, Maciej Górny says that the "Eastern" features allegedly characteristic of Poles were manifest particularly in reckless, immature and superficial behaviours, as well as in a lack of capacity for abstract and logical thinking and associating facts, and in drawing faulty conclusions. Effeminacy was not only ascribed to Poles, however; already in the $18^{\text {th }}$ century the French were described in similar terms by German intellectualists during the Napoleonic wars, in contrast to masculine Germans. ${ }^{13}$ In a study by Hubert Orłowski discussing the so-called "polnische Wirtschaft" 14 stereotype, he cites German lexicons of the $19^{\text {th }}$ century where Poles are referred to as "the French of the North". ${ }^{15}$

Thus, the emergence of stereotypes about features ascribed to particular nations or ethnic groups took rather surprising forms as far as their content and argumentation is concerned, while at the same time such a way of perceiving the world developed into ever more elaborate structures of stereotypization, with divisions not only into "fellows" and "strangers", i.e. foreigners, but also "fellow strangers". According to such divisions, the most Slavic Slavs were Slovaks, characterized by good-naturedness, modesty,

12 G. Klemm, Die Frauen. Kulturgeschichtliche Schilderungen des Zustandes Einflussesder Frauen in der verschiedenen Zonen und Zeitaltern, vol.1, Dresden 1854.

13 Cf. M. Górny, op.cit., 15-16.

14 H. Orłowski, „Polnische Wirtschaft”. Nowoczesny niemiecki dyskurs o Polsce, Olsztyn, 1998.

15 H. Orłowski, ibid., 151-152. 
diligence and devotion - at least this is how the issue was presented by the Slovak historian and national activist Frantisek Sasinek. ${ }^{16}$ Such a way of describing the political and social reality based on the analysis of Polish and Slavic characteristics was also popular in Poland. The critical descriptions of the Enlightenment reformers and the apotheoses of national character in Romanticism were followed by yet another critical and self-critical turn during nineteen-century Positivism.

Based on philosophy and the newly-emerged sciences of sociology and psychology, the Positivism of the $19^{\text {th }}$ century introduced new concepts of man and society. The founder of sociology, August Comte (1798-1857), described society as an organic and independent whole formed as a result of a primary need for living in a group. This instinctive drive to come together was determined, in his opinion, by three factors: family, division of labour, and religion, as well as the laws of the relatively permanent structure of the social organism, and the laws of social order and progress.

Another account of society based on psychology was developed by John Stuart Mill (1806-1873). He called psychology the science of social phenomena. In his opinion, the laws which apply to social phenomena are the laws of actions and emotions experienced by people living in a social state. ${ }^{17} \mathrm{He}$ was convinced that it was legitimate and methodologically substantiated to extend the findings of the sciences of man to the science of society. Living in a society is so natural, necessary and proper to man that he thinks about himself only as a member of some group. ${ }^{18}$

The $19^{\text {th }}$ century was not only a period of fascination with but also criticism of psychology. Directions emerging in social sciences included interpretations of social phenomena as derived from psychological ones as well as the distinctly anti-psychologist phenomenology of Edmund Husserl, expressed particularly in his

16 F.V. Sasinek, Die Slovaken. Eine ethnographische Skizze, 2nd ed., Prague 1875, 24.

17 J.S. Mill, A System of Logic, Ratiocinative and Inductive, New York 1882.

18 J.S. Mill, Utilitarianism, New York 1863. 
study entitled Logical Investigations. ${ }^{19}$ Psychologism in the social sciences consisted in explaining social facts as special cases of psychic processes. One of the representatives of this direction in sociology was Gustaw Le Bon (1841-1931), whose views were founded on a belief in the existence of a subconscious "collective soul" in organized assemblies of people. He claimed that: "To bring home convictions to crowds it is necessary first of all to thoroughly comprehend the sentiments by which they are animated, to pretend to share these sentiments, then to endeavour to modify them by calling up, by means of rudimentary associations, certain eminently suggestive notions, to be capable, if need be, of going back to the point of view from which a start was made, and, above all, to divine from instant to instant the sentiments to which one's discourse is giving birth." ${ }^{20}$

Equally interesting and at the same time controversial were his views on the nation and the so-called "soul of the race", ${ }^{21}$ seen as an indispensable binding element.

\section{JULIAN OCHOROWICZ ON PATRIOTISM AND THE POLISH NATIONAL CHARACTER}

The views of A. Comte, J.S. Mill, and G. Le Bon inspired the reflections on the national character of Poles by the philosopher and psychologist Julian Ochorowicz (1850-1917). Already in a paper he wrote as a student, entitled Jak należy badać dusze (How to Investigate the Soul), he introduced the notion of the soul not only to describe man's psychic life, but also in reference to a nation, using the term "the collective soul of nations". He believed that: "the laws governing

19 E. Husserl, Logical Investigations, London 1970.

20 G. Le Bon, The Crowd: A Study of the Popular Mind, New York 1895, 113-114.

21 G. Le Bon, The Psychology of Peoples, New York 1898. 
individual human souls are the same as those governing the collective souls of nations and the entire humankind."22

Ochorowicz thus claimed that the methods of investigating the soul of a nation are similar to those employed in examining the soul of an individual person. He believed that both the history of philosophy and the history of psychology were particularly useful in such examinations. He advocated the comparative-genetic method which helped not only differentiate between particular nations, but also identify factors affecting the development of the character of both individuals and societies, and show analogies in their development from infancy to adulthood. In addition, Ochorowicz saw a close relationship between the character of both individuals and groups and the place where they lived, the climate, the lay of the land, and other natural and geographical factors. His reflections on social phenomena may be summarized in two problems. He was first of all interested in the character of a community, and the conditions which shaped it. In his opinion, in order to understand, for instance, the problem of wars waged between nations, a matter of concern to everyone, it was not enough to analyse the economic and political conditions of life in the communities involved. It was much more important, he believed, to look at the nature of the nations concerned, their sentiments and desires, or their national character. Every community, Ochorowicz claimed, had a "soul" which became manifest through the structure of sentiments, thoughts, and the will, activated by external triggers due to a certain passivity of the people. Triggers activating this inert organism included, first of all, the circumstances in which a society emerged and the natural conditions in which it lived.

"People are ignorant rather than evil; it is a dormant power which should be awakened instead of being inebriated, enlightened rather than excited. It is an organism that is inert on its own, but furious when pressed by the circumstances. It lacks a will, but has impulses

22 J. Ochorowicz, Jak należy badać duszę, in: Z dziennika psychologa, Warszawa 1876. 
which may easily transform into convulsions. Let us create in it a will, and we will then be able to judge it according to the measure of freedom." 23

As a side remark, it is worth noting that Ochorowicz's reflections on crowd behaviour were formulated earlier than G. Le Bon's The Crowd: A Study of the Popular Mind. The latter was published in 1895, whereas Ochorowicz's thoughts were published already in 1880 in a study entitled Bezwiedne tradycie ludzkości (Unwitting Traditions of Mankind). Ochorowicz believed that psychology and history were sciences which explained both historical facts and social acts. As an advocate of a psychological approach to the examination of human groups, the Polish philosopher emphasized such important elements as the innateness of certain characteristics inherited from ancestors, including abilities, and tendencies, which form the experiential basis of a particular community. Through experience and tradition, the "collective man" becomes used to certain behaviours which, according to Ochorowicz, are the starting point for the development of customs and habits. Thus, the so-called inherited memory was related in his opinion to "the experience of ancestors deeply and frequently ingrained in the mind, capable of exerting a certain distant, unwitting influence on the temperament of today's descendants." 24

We may thus speak of two principles determining the history of mankind. For Ochorowicz, these are: the law of continuity - or tradition, and the law of opposition - or progress. Implementing Hegel's law of dialectics, in his reflections Ochorowicz notes that every institution, historical act, law, war, and theory, are to some extent a repetition of and an opposition to what has already been..$^{25}$ At the same time, he points out there are other rules governing

23 J. Ochorowicz, Pogadanki i spostrzeżenia z dziedziny fizjologii, psychologii, pedagogiki i nauk przyrodniczych, ebook/epub, 2015.

24 J. Ochorowicz, Bezwiedne tradycje ludzkości, Warszawa 1880, 23.

25 Ibidem, 216. 
a community as well, including the so-called rule of historic inertia, i.e. being accustomed to certain behaviours which, due to new circumstances, have lost their rationale. Another rule is that tradition means more to a society than progress; and yet another is the rule of automatism in cultivating traditions, or so-called "residual manifestations", that is the cultivation of certain customs without being aware of their genesis. These "residual manifestations" may, he believed, be a source of information on past facts, and reveal the genealogy of social behaviours. At the same time, when analysing such manifestations, certain immanent features of a nation can be identified. Ochorowicz believes that aside from the objective living conditions of a tribe, people or nation, there is also tradition, stored in a conscious or unconscious way, shaping the national character of a particular community. "Everything comes together in history, both great facts and little things. Like in physics, so in sociology nothing ever perishes, but is transformed. New things emerge from old, and old things are still present in the new." 26

Since individual behaviours are determined by psychical factors, Ochorowicz claims per analogiam that social behaviours depend on the psyche of a particular community. His position was expressed and illustrated in a work entitled Pierwiastki charakteru narodowego. Szkice z psychologii kultury pierwotnej Stowian centralnych (Elements of National Character. Sketches in the Psychology of the Primitive Culture of Central Slavs), published in Warsaw in 1907. The author compares the psychic characteristics of Slavs and Germans as revealed by the organization of their tribes. His descriptions of the virtues and faults of both communities are based on historical facts, as according to Ochorowicz every national feature we can observe today is rooted in the past, and while the living conditions may have changed, the customs developed and passed on from generation to generation have remained and become an element of the nation's

26 Ibidem, 148. 
soul, part of a national identity. Even earlier, in 1902, Ochorowicz had published an article in Tygodnik Ilustrowany in which he tried to answer the question "what is a nation?". The article was entitled What Is Nationality, and its main thesis was that nationality is an ethnographic feature which substantially differentiates nations in terms of statehood, faith, language, race, anthropological features, and culture. At the same time, however, these features play an integrating role, bringing individuals together to form a nation. In this unifying process, a very important role is played not only by objective, but also by subjective or emotional factors. One of them, Ochorowicz says, is a sense of patriotism. Thus, nationality should not be conceived as a notion or physical feature, but as a "predominantly psychic concept, in which the key components are not in skin, eye, or hair colour; advocacy of a particular form of government; attachment to a particular dress code or custom; the interests of a particular social class - be it capitalist or working, aristocratic or bourgeois; not even in the interest of all of them together - but in the heart." 27

Some interesting, though only partially unbiased views on the national character constituting the Polish national identity and the patriotism founded upon it, can be found in a study by Ochorowicz entitled Pierwiastki charakteru narodowego (Elements of National Character). ${ }^{28}$ Presenting the history of Poles from the time when the Slavic state was formed and the so-called ancestral patriotism emerged, he says: “(...) Slavs were once called Spori, from the Greek word sporaden, as it was not in aggregation, but in dispersion, sporadically, that their dwellings were scattered. While their settlements were dispersed, their cottages were adjacent, however. The Emperor Maurice writes that when settling on rivers,

27 J. Ochorowicz, Co to jest narodowość, Tygodnik Ilustrowany (1902)10-11, 209.

28 J. Ochorowicz, Pierwiastki charakteru narodowego. Szkic z psychologii i kultury pierwotnej Słowian centralnych (1907), in: O polskim charakterze narodowym, with an introduction by L. Gawor, Lublin 1986. 
marshes or impassable lake lands, they built their cottages so close to one another that, there being no space left in between, and all other land being covered with forests, swamps and marshes, anyone willing to travel through their country had to stop at their very doorstep, as more distant lands were often roadless and untrod. Tacitus describes German settlements at the times when they were no more sophisticated than the Slavic ones in an entirely different way. He says that Germans hated to have their houses adjacent to one another. They built their cottages separately, wherever any of them liked a grove, a plane or a spring (...) and there was plenty of open space left around every lodge." 29

Ochorowicz is of the opinion that even this description reveals differences in the national characteristics of Slavs and Germans, as he believes there is "(...) in Slavs an intimacy within the family and the house, but without much tribal connection; in Germans, general connection is greater, but families are less tightly-knit and the neighbourhood is less attached." 30

Ochorowicz's theoretical reflection on the idea of a nation was related to his main goal of understanding the national character of Poles. His purpose in analysing these issues was to contribute to healing the nation.

Therefore, Ochorowicz believes „(...) a certain familial and communal patriotism has developed in the people's character, and an accustomedness to a life that, while being independent, is so in a different way. (...) This has developed into a traditional sense of security and disregard for foreign raids. (...) While Germans treated every newcomer as an intruder, Slavs enjoyed seeing new people and became used to light-heartedly welcoming all incoming foreigners." 31

29 Ibidem, 39-40.

30 Ibidem, 40.

31 Ibidem, 41. 
Describing the behaviour of Poles as determined by the genealogical, geographical and economic criterion, he quotes the words of the famous traveller Ibrahim ibn Jacob, who said: "If Slavs were not divided into a multitude of generations and tribes, they could withstand any nation in the world." 32 Our ancestors continued to refuse monarchy even when other countries already had a strong and well-organised government. They did, however, embrace a certain order “(...) without which no society could survive, and this kind of social order, this bond between growing families, is also characteristic for them. They recognized authority, even despotic power, but only that of the sire. (...) Thus, the family was accustomed to obeying despotic power, but linked it only to the title of the sire." 33

As the family grew, the developing settlement was called "wieś" as it included "wsiech", that is "all" descendants of one forefather. It was thus a patrimony, or patria. It was the size of just such settlement, or hamlet, that the primary Slavic patriotism was limited to, even though the language, beliefs and customs were already common to a group much broader than the scope of such patriotism. The council of family sires made decisions on all matters. In practice, this meant that the father's authority was strictly obeyed by all family members. In a way, it was a monarchical kind of power. A council made up of the fathers of each family represented a kind of republican power.

"Thence the mixed features of monarchy and republicanism, especially where foreign-style monarchical institutions were introduced and clashed with long-established local governments, often republican, not limited by force or the admixture of foreign invasions. (...) In the family, there was despotism, but also unanimity, as the younger followed the opinion of the patriarch and did not aspire to decide about general matters. So when a council of family

32 Ibidem, 44.

33 J. Ochorowicz, Kształtowanie się stosunku do władzy, in: O polskim charakterze narodowym, op. cit., 49. 
fathers was formed, instead of a single family father, the question was what to do if they disagreed?" 34 Comparing Slavs with Germans, one could say that faced with a security threat, Germans mostly followed the majority opinion and disregarded the minority. Slavs, however, followed entirely different rules.

"The concepts of majority and minority did not exist (...) there was only a notion of unanimity inspired by the elders, and things were clear as long as the elders agreed; what was to be done, however, if even one of them was of a different opinion? (...) And thus some Slavic tribes, who did not want to accept the purely republican majority principle, bought their way out of this difficulty by prevailing upon the minority with sticks. While rather brutish as a method of persuading others about the need for unity, it was quite effective in having the principle upheld." 35

Such a way of agreeing upon procedural rules in the exercise of power proves there was a need for unanimity, and not just for a simple majority of votes. Besides, it appears that Slavs considered it just to punish those who evaded unanimity. In time, wooden sticks were replaced with "moral rods", but public opinion still strongly influenced decision-making, whether the decisions were objectively right or not. As a result, a failure to understand the need for different opinions, and thus of different parties, became noticeable in the Polish national character. ${ }^{36}$ It was an example of intolerance "(...) on this particular point of the state; it would be wrong to assume, however, that tolerance in general was alien to the Slavic nature. Tolerance in the Slavic nations was in many respects incomparably greater than elsewhere - for different reasons. Slavs were tolerant as a rule as they were uncommonly hospitable; as in their faith they were neither

34 Ibidem, 53.

35 Ibidem, 54.

36 cf. Ibidem, 54-55. 
fanatic nor drawn to apostolate; and finally, as more subtle matters of religion, science or even the state were of little interest to them." ${ }^{37}$

What about the intolerance mentioned by Ochorowicz, then? He believed that the hitting of one's adversaries with sticks did not mean disregard for their different opinion. On the contrary, it meant that the opponent's opinion actually mattered too much. If members of the family fathers council simply acknowledged opposing votes and moved on, they would in fact be ignoring them. This unanimity forced with sticks revealed a certain psychological paradox: "It was intolerance due to excessive respect for individual opinion. This paradox, a purely Polish one, is illustrated by the events that followed. One deputy could force an immediate end to an ongoing Sejm session by resorting to the liberum veto rule. By doing that, he fell into distain (moral rods) - but the Sejm session was ended! So the value of an individual opinion was still recognized, to the point that it was held in too much esteem! Not because anyone sensed even a trace of validity in that opinion, but because by inheritance, by addiction, unwittingly, everyone felt the sad necessity to respect each deputy's vote, as though each deputy was still the father of a family, self-governed and infallible." 38

Law in Slavic countries was respected less strictly, Ochorowicz claimed, than by the Anglo-Saxon race, or, to be more exact, the Celtic and German race descended from squads of knights and bandits, taught to blindly obey their superiors. In his opinion, Poles respected law as long as it was ancient, customary; new laws enacted by various forms of government were not necessarily respected. Interestingly, the more centralized the power was, the weaker it became. Chieftains were elected from among the elders mostly during war, so that they could manage the defence singlehandedly. During peace, their power was more nominal than real, as it boiled down mostly

37 Ibidem, 55.

38 Ibidem, 56. 
to "(...) upholding customary laws and adjudicating in disputes." 39 Among the many features mentioned in the above descriptions, which Ochorowicz believed to be Polish faults, one played a key role in the existence of the Polish nation. Ochorowicz claimed that it was the lack of spiritual cohesion and affinity of thought in everyday life. The fact such cohesion only appeared on rare occasions attested to the nation's immaturity. Another interesting study by Ochorowicz, which deserves to be discussed in the context of patriotism and national identity, is entitled Our Selfness, or the Polish Individualism, ${ }^{40}$ and it is based on a study by J. Kaliszewski. ${ }^{41}$ Looking at Poles with a critical eye, Ochorowicz refers to such faults in our national character as impetuosity, irascibility and self-will. He says a Pole is easily angered, which makes him disrespectful, impolite, unsociable, and often intolerant of the beliefs of others, even though Poles are said to be the second most polite nation in Europe, next to the French. "Courtliness, gallantry, token cordiality, men kissing one another on both cheeks, a custom practically unknown in the West (...) partially derive from imitating the East, and partially from the tradition of that cordiality which truly existed between nobility as one large interrelated family. (...) The French, less demonstrative in their forms, less cordial, but even more courtly, are in fact downright insincere in their polite manners and promises (...) knowing in advance that these are but general customary forms inevitable among well-bred gentlemen, which can only be taken seriously by a foreigner." 42

Aside from these faults, Poles are characterised by a certain kind of selfness. Ochorowicz defines this feature of the Polish nature by

39 Ibidem, 57.

40 J. Ochorowicz, Psychologia, pedagogika, etyka. Przyczynki do usiłowań naszego odrodzenia narodowego, Warszawa 1917. The passages analysed in this article are taken from the following collection: Nasze wady narodowe and Nasze osobnictwo, in: O polskim charakterze narodowym, op. cit., 59-79.

41 J. Kaliszewski, Moi kochani rodacy, Warszawa 1888.

42 J. Ochorowicz, O polskim charakterze narodowym, op. cit., 61-62. 
explaining what it is not. Thus, selfness is not selfishness, as it is not about material gains. Neither can it be called individualism, which has positive connotations, while selfness is a fault. It is not lawlessness, which requires some bravery and originality, nor sluggishness, as this would prevent people from developing social bonds. The notion of selfness is related to a particular understanding of equality, founded on so-called noble equality.

"In the West, nobility served as the king's guards; in the East - they were the tsar's slaves. In Poland, there was equality, but only between the magnate and the king - such as was not seen anywhere else. There was no equality between the nobility and the rest of the nation, just like everywhere else, with the sole difference that where others might emphasize hierarchy with its multiple grades, we emphasized the formal equality of the entire noble class." ${ }^{43}$

According to Ochorowicz, Poles are thus "a thoroughly aristocratic nation" and everyone holds in contempt all those who are beneath them on the social ladder. "Which does not prevent them from bowing down to one another even as they are climbing up (...) Polish equality is a fiction." 44

Emphasizing the fictionality of Polish equality, he makes it clear, however, that he is not an advocate of the utopian kind of equality proposed by J.J. Rousseau, which the French only embraced by dressing up as shepherds and shepherdesses in what was no more than a fleeting fad.

"Complete equality has never been and will never be, as long as human nature remains what it is. And philosophical or religious equality has never interfered with social or societal inequality. The only point is that we should truly recognize equality in law and in labour, so that it enters our bloodstream and is incorporated into our institutions - first into our forms of social life. This can

43 Ibidem, 64-65.

44 Ibidem, 65. 
only be achieved by common schools, by uprooting the disdain for certain professions and instilling more respect for any kind of diligent work, while developing disgust for even the most sophisticated sluggishness." 45

One could say that the source of our selfness is in aristocratic individuality and an expectation of tributes and homages which are not always due. This particular hypersensitivity often prevents objective evaluation of one's own possibilities, not to mention the perception of one's own faults. Excessive individualism thus hinders Poles in establishing organizations, associations and various forms of cooperation. It should be noted, however, that Poles hate overt despotism, but suffer undercover despotism quite easily. In times of celebration, when the overall emotional temperature rises and patriotic feelings well up, Poles behave differently. Ochorowicz has an ambivalent attitude to such emotional spikes. The so-called festive Pole suffers despotism more readily, excited by national slogans and patriotism. Things may be even worse, though, "(...) if the one who has embraced dictatorship fails to exercise it sufficiently well. Which was usually the case in Poland, when the lead was taken under pressure by people of a purely Polish character, such as the Chłopicki or Skrzynecki family. Besides, our indiscipline, our lawlessness are revealed less often in the military sphere - and more often in everyday civilian work." 46

The Poles' selfness was a national fault which, according to Ochorowicz, prevented the development of a well-organised and well-performing governmental structure. In the case of Germans, the foundation for the development of their statehood, or unity, was in a way already included in their very name.

"In the name of this people, there is one late-French word: guerre=war, and one German word: mann=man. They were war

45 Ibidem, 66.

46 Ibidem, 71. 
troops, submitted to the authority of one chieftain, consisting of various elements, not affiliated and not familiar with the advantage of paternal authority." ${ }^{77}$ They could develop strict and rigorous organizations in the course of long-range expeditions, commercial trade and development of business skills, but first of all when organizing an invasion, where belligerence and absolute obedience to the leader warranted discipline as well as integrity and spiritual unity.

Ochorowicz's reflections, published at the beginning of the $20^{\text {th }}$ century before Poland regained its independence after years of partitions, are quite significant. He believed that the spiritual unity of Poles was less frequently evidenced in the history of our nation than selfness, and claimed that the truly patriotic efforts for the common good of all Poles were the Constitution of May 3, 1791, and the Kościuszko Uprising.

\section{SUMMARY}

The above analysis of the Poles' national character and identity based on Ochorowicz's views suggests the need for an in-depth reflection on the history of Poland, its rises and falls in particular, which should act as a warning against the mistakes of the past. The opposite tendency, consisting in a kind of reassuring therapy which results in historical analysis that excessively glorify patriotic and national events, is not a reliable approach to research. Sugar-coating the history of a nation, often emphasizing its patriotism and sacrifice while disregarding facts, may be treated as excessive loyalty and gratefulness to a nation, but also as excessive loyalty to a government. In turn, such a coincidence of patriotism with gratefulness and loyalty to a government may often lead to morally ambiguous partiality.

47 Ibidem, 77. 
Ochorowicz's reflection on such social issues as national character and national identity does not, however, represent a well-developed theory. His intention was first of all to emphasize the educational and ethical functions and aspects of his analysis, and to demonstrate the national dimension of morality. Thus, a discussion of the reasons for certain social behaviours and the genealogy of the faults and virtues of the Polish nation contributed, according to Ochorowicz, to understanding the national character of Poles. His training as a philosopher, psychologist and sociologist enabled him to focus on identifying the rules of community development, at times falling into the trap of stereotypical simplifications. The main conclusion of his reflections boils down to the claim that while the reasons for all social change come from external conditions, the direct driving force behind them are sentiments generated by the psychology of communities and social groups. This concept appears to have been significantly affected by Herbert Spencer's theory of evolutionism, ${ }^{48}$ which contends that the opinions ultimately prevailing in a society are shaped more by sentiments than reason, and individual efforts in striving towards happiness are a sine qua non condition for the happiness of a society as a whole. Using Spencer's paradigm, Ochorowicz argues that while the dynamics of social change may be slowed down under the influence of the past, they nevertheless follow the line of progress. It is impossible to eliminate periods of backwardness, and development may have its rises and falls. Ochorowicz believes that if we take science and industry as the basic criterion for development, then the societies of Western Europe are in the lead. As the author of the philosophical

48 The English sociologist claimed that societies change in their degree of complexity and type of social organization. Consequently, some move to higher degrees of complexity, while others retrogress to lower degrees. It is the struggle between societies that, when a clash occurs between them, usually results in the more complex ones, which have greater military and economic power, to prevail over less developed societies. Spencer applied the law of natural selection not to individuals or social classes, but to societies, or, more precisely, to certain types of social organizations. 
programme of "Warsaw Positivism", Ochorowicz was involved in the programme of organic work and implemented his own concept of ethics. Describing and classifying moral facts, as well as identifying their sources and rules of development are the first task of a version of ethics called ethology. Its second task is to develop rules of conduct and turn them into specific norms based on empirical knowledge about man. The knowledge of man which provides the foundations for empirical ethics should be sought, Ochorowicz believed, in our psychological knowledge about human nature. Therefore, grounding ethical programmes on an empirical, psychological basis, was required in order to avoid utopian reforms aimed at transforming moral life. Ochorowicz's illustration of Polish national faults and his identification of their sources are an example of ethology, since the subject matter of such ethics was moral facts analyzed using the method of description and explanation, just like in the natural sciences. Ochorowicz ${ }^{49}$ listed the following subfields of descriptive ethics: ethogenesis - addressing questions about the development of moral notions; moral ethnography - describing the moralities of different tribes and nations; the general history of morality; systems of religious ethics; the ethics of everyday life (i.e. principles man refers to when evaluating actions); and political ethics. Remedies aimed at transforming the national character and directions about how it should be developed are an example of ethoplasty, i.e. the practical application of theoretical norms. Ochorowicz supplemented ethical issues with sociological considerations, which in his reflections focused mostly on the concept of a nation and the processes contributing to its formation. The reason for such narrowing down was, among other factors, the situation in which Poland found itself during the partitions, as well as the discussions held in the leading scientific circles in Europe. Ochorowicz believed in the existence of certain human communities, each having its own collective soul

49 J. Ochorowicz, Metoda w etyce, Przegląd Filozoficzny (1906), 53. 
irreducible to the sum total of individual souls. The basic element of each community is man, its paramount architect and creator. Every such community develops its own characteristic emotional relationships. Understanding individual psyche does not warrant understanding group psychology, however. While the improvement of individual characters is one of the main foundations of communal development, it is not a sufficient condition. Ochorowicz believed that the development of spiritual bonds in a nation originated in the family, but was just as significantly influenced by literature, art, science, organizations, the workplace, and other social institutions.

\section{REFERENCES}

Adamowsky E., Euro-Orientalism, Liberal Ideology and the Image of Russia in France, Bern 2006.

Le Bon G., The Psychology of Peoples, New York 1898.

Le Bon G., The Crowd: A Study of the Popular Mind, New York 1896.

Chałasiński J., Spoteczna genealogia inteligencji polskiej, Warszawa 1946.

Dmowski R., Myśli nowoczesnego Polaka, Lwów 1907.

Drabarek A., Mit jako czas skondensowany, Przegląd Filozoficzny - Nowa Seria 14(2005)3, 39-45.

Drabarek A., Kategoria ojca w pogladach Pierre Legendre, Psychologia Wychowawcza 48(2014), 108-118.

Drabarek A., Wartości w demokracji, Warszawa 2012.

Górny M., Próby profesjonalizacji refleksji nad charakterem narodowym w XIX wieku, in: Klio Polska. Studia i materiaty z dziejów historiografii polskiej XIX i XX wieku, Vol. 6, Warszawa 2012, 11-36.

Hesse H., Mysli, Lublin 1996.

Kaliszewski J., Moi kochani rodacy, Warszawa 1888.

Klemm G., Die Frauen. Culturgeschichtliche Schilderungen des Zustandes Einfussesder Frauen in der werschiedenen Zonen und Zeitaltern, vol. 1, Dresden 1854.

Kołakowski L., Obecnośc mitu, Wrocław 1994.

Loesch K.Ch. von, Der polnischeVolkscharakter. Urteile und Selbstzeugnisseausvier Jabrbunderten, Junker und Dunnhaupt, Berlin 1940.

MacIntyre A., Is Patriotism a Virtue?, in: Debates in Contemporary Political Philosophy: An Anthology, eds. D. Matravers, J.E. Pike, New York 2003. 
Mill J.S., Utilitarianism, New York 1863.

Mill J.S., A System of Logic, Ratiocinative and Inductive, New York 1882.

Ochorowicz J., Jak należy badać duszę, in: Z dziennika psychologa, Warszawa 1876.

Ochorowicz J., Bezwiedne tradycje ludzkości, Warszawa 1880.

Ochorowicz J., Metoda wetyce, Przegląd Filozoficzny 1(1906)1, 2-15.

Ochorowicz J., Pierwiastki charakteru narodowego. Szkic z psychologii i kultury pierwotnej Stowian Centralnych, Warszawa 1907.

Ochorowicz J., Psychologia, pedagogika, etyka. Przyczynki do usitowań naszego odrodzenia narodowego, Warszawa 1917.

Ochorowicz J., Pogadanki i spostrzė̇enia z dziedziny fizjologii, psychologii, pedagogiki i nauk przyrodniczych, ebook/epub 2015.

Orłowski H., "Polnische Wirtschaft". Nowoczesny niemiecki dyskurs o Polsce, Olsztyn 1998.

Sasinek F.V., Die Slovaken. Eine ethnographische Skizze, 2ndedition, Prague 1875.

Sebald H., Studying National Character Trough Comparative Content Analysis, Social Forces 40(1962)4, 318-322.

ANNA DRABAREK

adrabarek@gmail.com

Maria Grzegorzewska Pedagogical University, Institute of Philosophy and Sociology

Szczęśliwicka 40, 02-353 Warsaw, Poland

DOI: 10.21697/spch.2019.55.3.03 